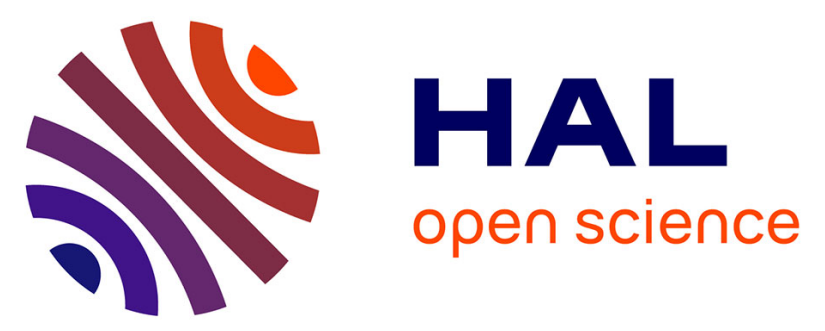

\title{
A proton complex of p-tert-butylcalix[4]arene- tetrakis(N,N-dimethylthioacetamide): NMR evidence and probable structure
}

Jaroslav Kriz, Jiri Dybal, Emanuel Makrlik, Petr Vanura, Jan Lang

\section{To cite this version:}

Jaroslav Kriz, Jiri Dybal, Emanuel Makrlik, Petr Vanura, Jan Lang. A proton complex of ptert-butylcalix[4]arene-tetrakis(N,N-dimethylthioacetamide): NMR evidence and probable structure. Supramolecular Chemistry, 2007, 19 (6), pp.419-424. 10.1080/10610270601089360 . hal-00513497

\section{HAL Id: hal-00513497 \\ https://hal.science/hal-00513497}

Submitted on 1 Sep 2010

HAL is a multi-disciplinary open access archive for the deposit and dissemination of scientific research documents, whether they are published or not. The documents may come from teaching and research institutions in France or abroad, or from public or private research centers.
L'archive ouverte pluridisciplinaire HAL, est destinée au dépôt et à la diffusion de documents scientifiques de niveau recherche, publiés ou non, émanant des établissements d'enseignement et de recherche français ou étrangers, des laboratoires publics ou privés. 


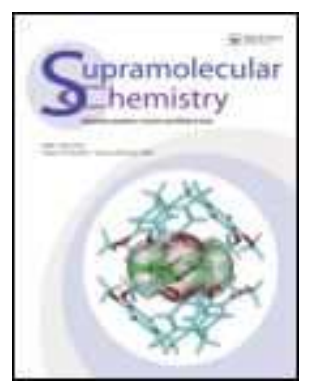

\section{A proton complex of p-tert-butylcalix [4] arene-tetrakis $(\mathrm{N}, \mathbf{N}$ - dimethylthioacetamide): NMR evidence and probable structure}

\begin{tabular}{|c|c|}
\hline Journal: & Supramolecular Chemistry \\
\hline Manuscript ID: & GSCH-2006-0077.R1 \\
\hline Manuscript Type: & Communications \\
\hline $\begin{array}{r}\text { Date Submitted by the } \\
\text { Author: }\end{array}$ & 12-Oct-2006 \\
\hline Complete List of Authors: & $\begin{array}{l}\text { Kriz, Jaroslav; Institute of Macromolecular Chemistry, Structure } \\
\text { Analysis } \\
\text { Dybal, Jiri; Institute of Macromolecular Chemistry, Structure } \\
\text { Analysis } \\
\text { Makrlik, Emanuel; University of West Bohemia, Faculty of Sciences } \\
\text { Vanura, Petr; Prague Institute of Chemical Technology } \\
\text { Lang, Jan; Faculty of Mathematics and Physics, Charles University }\end{array}$ \\
\hline Keywords: & Calixarene complex, protonation, NMR, DFT \\
\hline \multicolumn{2}{|c|}{$\begin{array}{l}\text { Note: The following files were submitted by the author for peer review, but cannot be converted } \\
\text { to PDF. You must view these files (e.g. movies) online. }\end{array}$} \\
\hline $\begin{array}{l}\text { CXS-Sch1.CDX } \\
\text { CXS-Fig3a.tif.sit } \\
\text { CXS-Fig3b.tif.sit } \\
\text { CXS-Fig4a.tif.sit } \\
\text { CXS-Fig4b.tif.sit }\end{array}$ & \\
\hline
\end{tabular}

\section{今 ScholarONE" \\ Manuscript Central}




\title{
A proton complex of $p$-tert-butylcalix[4]arene-tetrakis( $N, N$ - dimethylthioacetamide): NMR evidence and probable structure
}

\author{
JAROSLAV KŘÍǏ ${ }^{*}$, JIŘÍ DYBAL ${ }^{a}$, EMANUEL MAKRLÍK ${ }^{b}$, PETR VAŇURA $^{c}$, and \\ JAN LANG ${ }^{c, d}$
}

\begin{abstract}
${ }^{a}$ Institute of Macromolecular Chemistry, Academy of Sciences of the Czech Republic, Heyrovského sq. 2, 16206 Prague, Czech Republic.E-mail: kriz@imc.cas.cz

${ }^{b}$ Faculty of Applied Sciences, University of West Bohemia, Husova 11, 30614 Pilsen, Czech Republic.

${ }^{c}$ Prague Institute of Chemical Technology, Technická 5, 16628 Prague, Czech Republic.

${ }^{d}$ Department of Low Temperature Physics, Faculty of Mathematics and Physics, Charles University, V Holešovičkách 2, 18000 Prague, Czech Republic.
\end{abstract}

Using ${ }^{1} \mathrm{H}$ and ${ }^{13} \mathrm{C}$ NMR together with density functional theoretical (DFT) calculations, we show that $p$-tert-butylcalix[4] arene-tetrakis $(N, N$-dimethylthioacetamide) (1) forms a stable equimolecular complex with proton in the form of hydroxonium ion in nitrobenzene- $d_{5}$. Protons were offered by hydrogen bis(1,2-dicarbollyl) cobaltate (HDCC) and converted to hydroxonium ions by traces of water. The complex $1 \cdot \mathrm{H}_{3} \mathrm{O}^{+}$ adopts a slightly asymmetric but rapidly motionally averaged conformation, which is distinctly more cone-like than ligand 1 . The hydroxonium ion $\mathrm{H}_{3} \mathrm{O}^{+}$is bound partly to thiocarbonyl sulphur atoms and partly to phenoxy oxygen atoms of 1 by strong hydrogen bonds and other electrostatic interactions.

Keywords: Calixarene complex; protonation; NMR; DFT

\section{INTRODUCTION}

Calixarene-based molecules produced in rich diversity [1] have received intense attention in the last years. The some calixarenes having four and five member rings bear some resemblance to the natural cyclodextrins [2] in as much they posses a cone-like cavity, which is able to act as a host for a number of guest molecules. As such, they find applications as 
selective binders and carriers, analytical sensors, catalysts and model structures for biomimetic studies [1].

In addition, they can be modified by attaching carbonyl, ester, amide or thioamide groups to their lower rim. Due to their number (usually four or more) and restricted conformation, these groups often serve as efficient coordination site for various cations. Many studies have focused on their binding ability toward metal ions, predominantly alkali and alkaline-earth but also transition and heavy metal cations. [3-11] As experimentally proved, coordination of a metal ion to the groups (say carbonyls) at the lower rim exerts a conformation change on the whole calixarene unit, which usually adopts a more cone-like form changing thus subtly its host properties for a guest molecule. The actual conformation change appears to be strongly dependent on the nature of the ion as well as the calixarene itself. The study of ion coordination to modified calixarenes, including non-metallic ions, first of all proton or hydroxonium ion, thus can be of primary interest to supramolecular chemistry.

Up to now, no complex of proton with any calixarene has been reported. We have studied interactions of $\mathrm{H}_{3} \mathrm{O}^{+}$with calix[4]arenes bearing ester, amide and thioamide groups. All of these substances clearly form an equimolecular complex with $\mathrm{H}_{3} \mathrm{O}^{+}$. However, the dimethylamide-derivative apparently is not available in a sufficiently pure form, the commercial product being partly complexed with $\mathrm{Na}^{+}$ions and thus not suitable for demonstrative purposes. The interaction of the analogue bearing ester groups is somewhat complicated and will be described in a separate study. [18] In this work, we present NMR evidence for a complex of $\mathrm{H}_{3} \mathrm{O}^{+}$with the thioacetamide derivative known as lead ionophore, namely $p$-tert-butylcalix[4]arene-tetrakis(N,N-dimethylthioacetamide) (1, cf. Scheme 1). On the grounds of ${ }^{1} \mathrm{H}$ and ${ }^{13} \mathrm{C}$ NMR spectra and DFT calculations, we suggest its most probable structure. 


\section{RESULTS AND DISCUSSION}

Similarly as in our previous papers [13,14], hydrogen bis(1,2-dicarbollyl)cobaltate (HDCC) (Ref.12, for structure see Scheme 1) as a proton source, was used in nitrobenzene- $d_{5}$. A $2.5 \mathrm{~mol}$ excess of water to $\mathrm{HDCC}$ converts the protons to the hydroxonium ions $\mathrm{H}_{3} \mathrm{O}^{+}$. HDCC is well soluble in nitrobenzene, but calixarene $\mathbf{1}$ did not allow concentrations above $5 \times 10^{-3} \mathrm{~mol} / \mathrm{L}$.

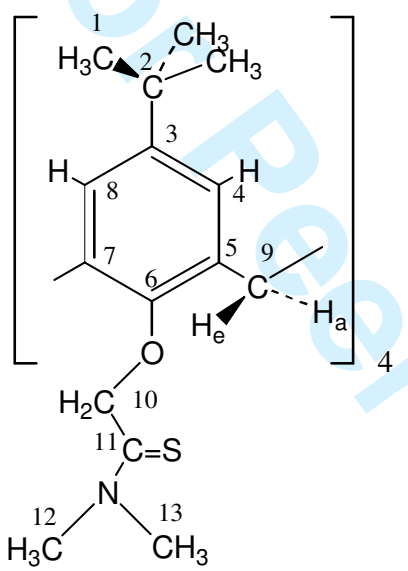

1

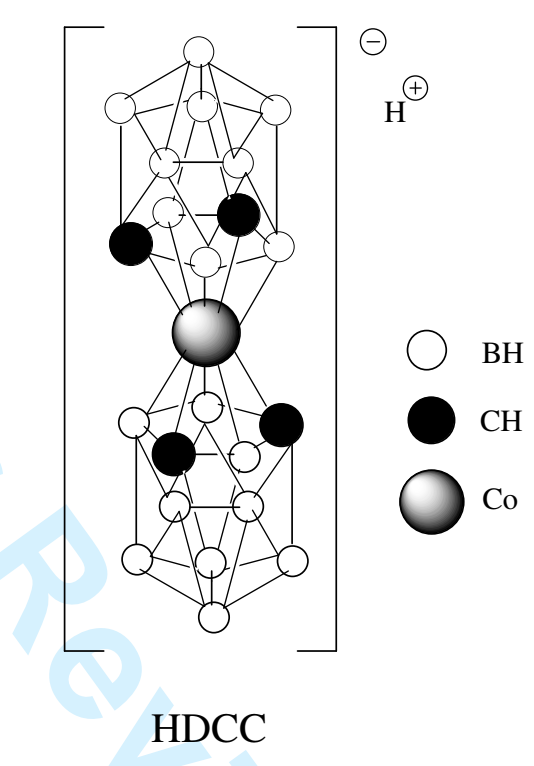

Scheme 1

In the following NMR spectra, the signal assignment (which was checked by means of 2D COSY-LR and NOESY NMR spectra for ${ }^{1} \mathrm{H}$ and HSQC and HMBC spectra for ${ }^{13} \mathrm{C}$ ) corresponds to Scheme 1 where the protons have the same number as the carbons they are attached to. Figure 1 shows ${ }^{1} \mathrm{H}$ NMR spectra of $\mathbf{1}$ and its 2:1 and 1:1 mol/mol mixtures with HDCC in nitrobenzene- $d_{5}$. There are relative shifts of almost all signals in a similar direction and magnitude as in the case of complexation of metallic ions by calixarene ligands [3-5], evidencing the formation of a complex of $\mathbf{1}$ with $\mathrm{H}_{3} \mathrm{O}^{+}$(in Fig. 1B, the signal of proton 13 is broadened and placed under the number 6). Under higher excess of HDCC, no further shift is observed proving thus that the complex is equimolecular and its stability constant is high 
(well above $10^{3}$ ). At HDCC/1 ratios between 0 and $1 \mathrm{~mol} / \mathrm{mol}$, the signals gradually shift and broaden. At the ratio 1:1, the signals are further shifted but narrow again. Evidently, an exchange between free and bound ligand $\mathbf{1}$ takes place. Its rate is only moderate considering the signal broadening. The corresponding correlation times of exchange $\tau_{\mathrm{ex}}$ (in ms) calculated from the broadening of the signals and the relative shifts between the free and bound states are given in Fig. 1 B, while the relative shifts are shown in Figure $1 \mathrm{C}$. These values are rather formal, however, considering the complexity of motions discussed below.

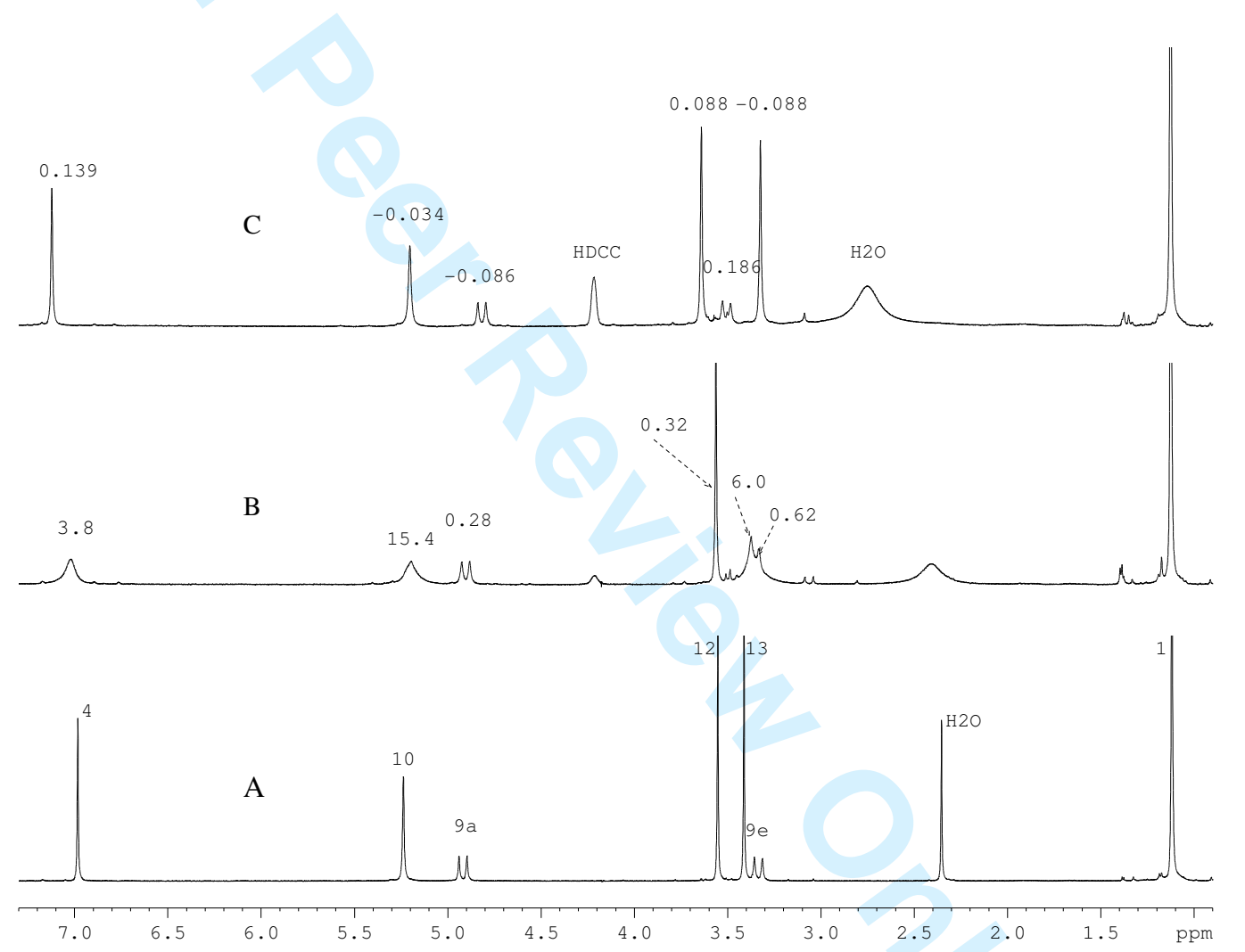

Fig. $1{ }^{1} \mathrm{H}$ NMR spectra of $0.005 \mathrm{~mol} / \mathrm{L}$ solution of $\mathbf{1}$ (A) and its 2:1 (B) and 1:1 (C) (mol/mol) mixtures with HDCC. Signal assignment (cf. Scheme 1) in A, approximate exchange correlation times $\tau_{\mathrm{ex}}$ (in ms) in B, relative chemical shifts (in ppm) in C.

Two dynamic processes are clearly operative here: i) a fast exchange between free and bound ligand 1 and ii) the pinched cone - pinched cone interconversion. It is well documented that calix[4]arene derivatives adopt a pinched cone conformation with $\mathrm{C}_{2 \mathrm{v}}$ symmetry of the macrocycle (neglecting conformations of the lower rim substituents that may further decrease 
the actual symmetry) rather than the effective $\mathrm{C}_{4}$ symmetry that can be deduced from $1 \mathrm{H}$ NMR spectra [15,19]. The average spectral shape is caused by a rapid interconversion between two identical structures (pinched cone). The free energy barrier is usually as low as 9 $\mathrm{kcal} / \mathrm{mol}$ [19], which makes this motion fairly difficult to be detected by NMR. A significant line broadening due to this process occurs at very low temperatures (around $188 \mathrm{~K}$ ) when most of solvents become frozen. An evidence of the pinched cone conformation of $\mathbf{1}$ is also a chemical shift difference of the axial and equatorial bridging methylene protons 9 [15], which is as large as $1.534 \mathrm{ppm}$.

It is obvious that attachment of hydroxonium or metal cation hinders the pinched cone - pinched cone interconversion. In the presence of the fast chemical exchange of hydroxonium cations (on $1 \mathrm{H}$ chemical shift time scale), the calix[4]arene molecule is allowed to interconvert only in between the periods when the complex is formed. This results in overall decrease of pinched cone - pinched cone inteŕconversion rate and thus broadening of some of the signals.

When all of $\mathbf{1}$ is bound to $\mathrm{H}_{3} \mathrm{O}^{+}$, the calix[4] arene part of the molecule is fixed in a $\mathrm{C}_{4}$ symmetry so that no interconversion takes place and the NMR signals are narrow again. The decrease of the difference of chemical shifts of diastereotopic methylene protons 9 to 1.311 ppm shows that the cavity adopts a flatter, more cone-like form, presumably due to nearer proximity of the lower-rim polar groups interacting with $\mathrm{H}_{3} \mathrm{O}^{+}$. Despite of the high stability constant of the complex, the hydroxonium cation remains mobile and it samples different orientations within a single ligand averaging thus the whole structure so that there is only one set of signals in Figure 1C.

Somewhat more information about the structure of the complex $1 \cdot \mathrm{H}_{3} \mathrm{O}^{+}$can be obtained from ${ }^{13} \mathrm{C}$ NMR spectra depicted in Figure 2. In order to overcome the low sensitivity at $5 \mathrm{mmol} / \mathrm{L}$ concentration and overshadowing by huge signals of nitrobenzene- $d_{5}$, four types 
of DEPT45 and DEPT-LR spectra are combined here. The signals of C=S carbon 11 did not show up in DEPT spectra but can be found in ordinary ${ }^{13} \mathrm{C}$ NMR spectra, their shifts being 197.97 and 195.99 ppm in $\mathbf{1}$ and the complex, respectively. The down-field shifts of carbon signals 4(8) and 5(7) probably indicate formation of the conical structure that is close to $\mathrm{C}_{4}$ symmetry. Quite similar ${ }^{13} \mathrm{C}$ complexation induced shifts were reported by Arduini et al. [4] for complex of tetraamide derivative of calix[4]arene with KSCN. The up-field shift of 6 may be attributed to a decreased electron density on the phenoxy oxygen atom due to a hydrogen bond with $\mathrm{H}_{3} \mathrm{O}^{+}$. At the same time, 1.98 ppm up-field shift of carbon 11 shows a strong hydrogen bond of the ion $\mathrm{H}_{3} \mathrm{O}^{+}$with a $\mathrm{C}=\mathrm{S}$ group. As these shifts indicate really strong hydrogen bonds, the most probable structure appears to be that of $\mathrm{H}_{3} \mathrm{O}^{+}$directly bonded to both phenoxy oxygen and thiocarbonyl sulphur atoms. We have only one signal for each type of carbon including 11 , which indicates a $\mathrm{C}_{4}$ symmetry of the whole molecule; the simplicity of the corresponding proton spectrum points to the same conclusion. As it is hardly possible to have the $\mathrm{H}_{3} \mathrm{O}^{+}$ion equally bound by hydrogen bonds to all four $\mathrm{C}=\mathrm{S}$ groups and all four phenoxy oxygen atoms as well we have to assume a rapid motion of $\mathrm{H}_{3} \mathrm{O}^{+}$within the coordination site averaging the structure in the time window of NMR (see below).
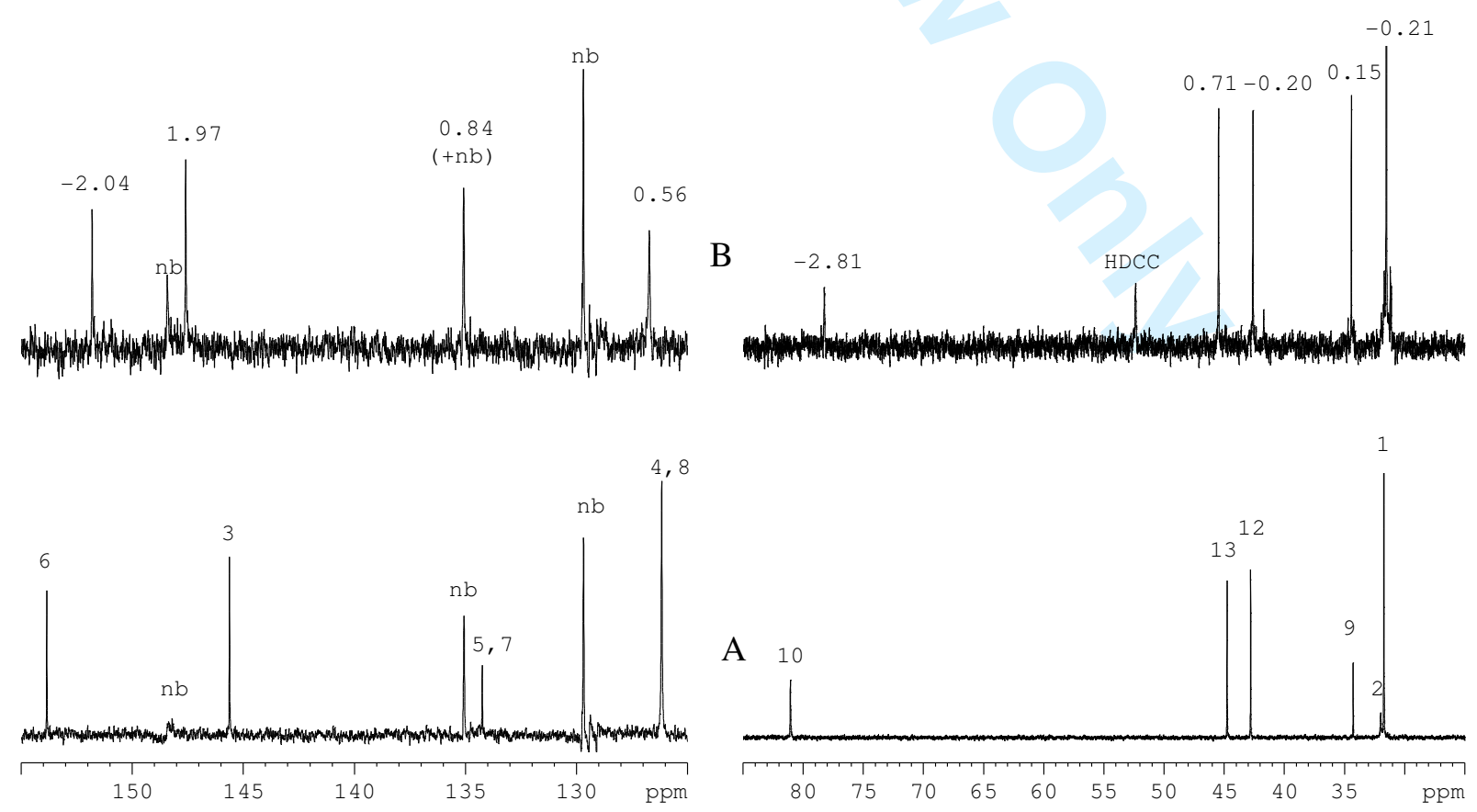
Fig. 2 Combined ${ }^{13} \mathrm{C}$ NMR DEPT45 and DEPT-LR spectra of $0.005 \mathrm{~mol} / \mathrm{L}$ solution of 1 (A) and its 1:1 (mol/mol) mixture with HDCC (B). Signal assignment (cf. Scheme 1) in A, relative chemical shifts (in $\mathrm{ppm}$ ) in $\mathrm{B}$; in both parts, nb means residual signals of nitrobenzene.

In order to confront our experimental findings with theoretical predictions, the equilibrium geometries of ligand $\mathbf{1}$ and its complex with $\mathrm{H}_{3} \mathrm{O}^{+}$were calculated at the B3LYP/6-31G(d) level. DFT calculations have been found to offer good results for H-bonded structures [20] although their full reliability in this field was recently criticized [21,22]. However, recommended more rigorous methods like Moeller-Plesset perturbation approach MP2 [21] or modified functionals with wider basis sets [22] are not practicable for such large systems as $\mathbf{1}$ or its complex. Considering the rather mild deviations apparently produced by the conventional DFT method, we believe that our calculations give a reasonable approximation to our structures.

In Fig. 3, the optimized structure of $\mathbf{1}$ is given. As it can be seen, the cone is predicted to be distorted in the way suggested by NMR, i.e. two opposite aromatic rings are much more parallel than it would be expected in ligand 1. As explained above, it is in a good agreement with NMR spectra.

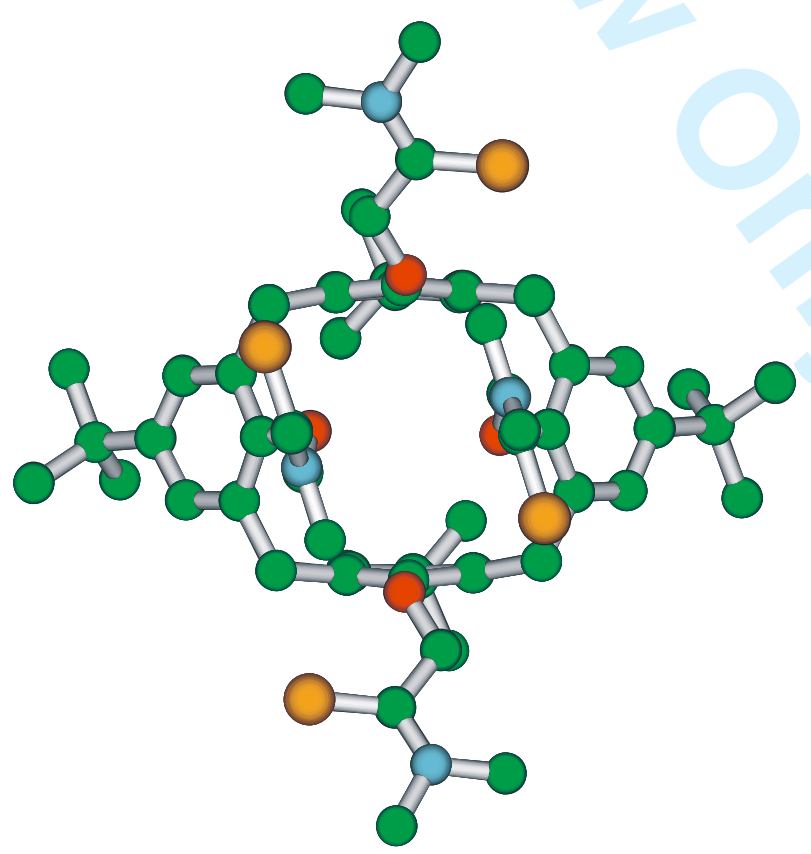




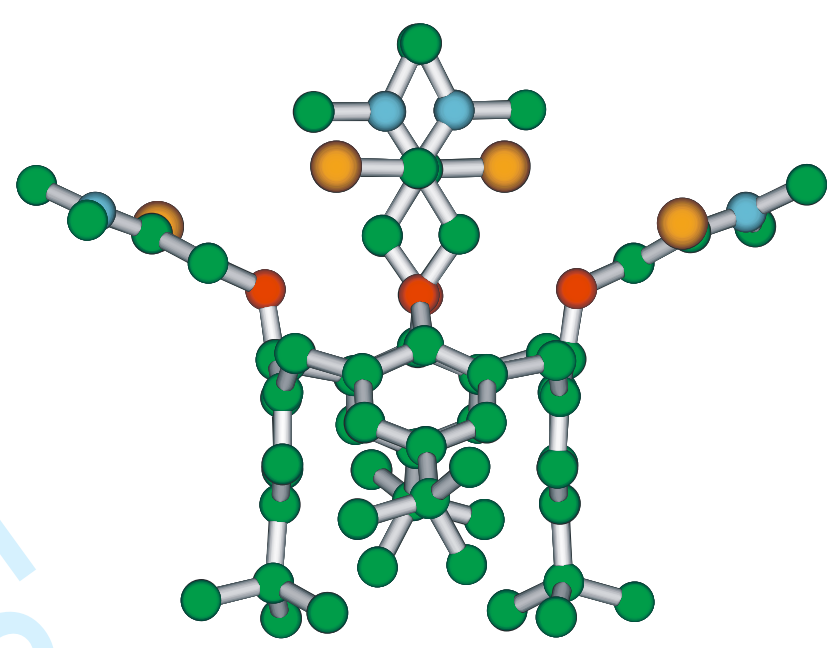

Fig. 3 Two projections of the DFT-optimized structure of free 1 (B3LYP/6-31G(d), hydrogen atoms omitted).

In Fig. 4, the lowest-energy-level structure obtained by optimization of the $\mathbf{1} \cdot \mathrm{H}_{3} \mathrm{O}^{+}$ complex is illustrated. In good agreement with NMR, the calixarene part of the considered complex is more cone-like and distinctly more symmetric than free ligand $\mathbf{1}$. The hydroxonium ion, also in agreement with NMR, is bound by two strong H-bonds to phenoxy oxygen atoms as well as by a two-center H-bond to thiocarbonyl sulphur and phenoxy oxygen atoms. Considering their orientation, the remaining two thiocarbonyl sulphur atoms are probably bound by electrostatic interaction with $\mathrm{H}_{3} \mathrm{O}^{+}$, too. 

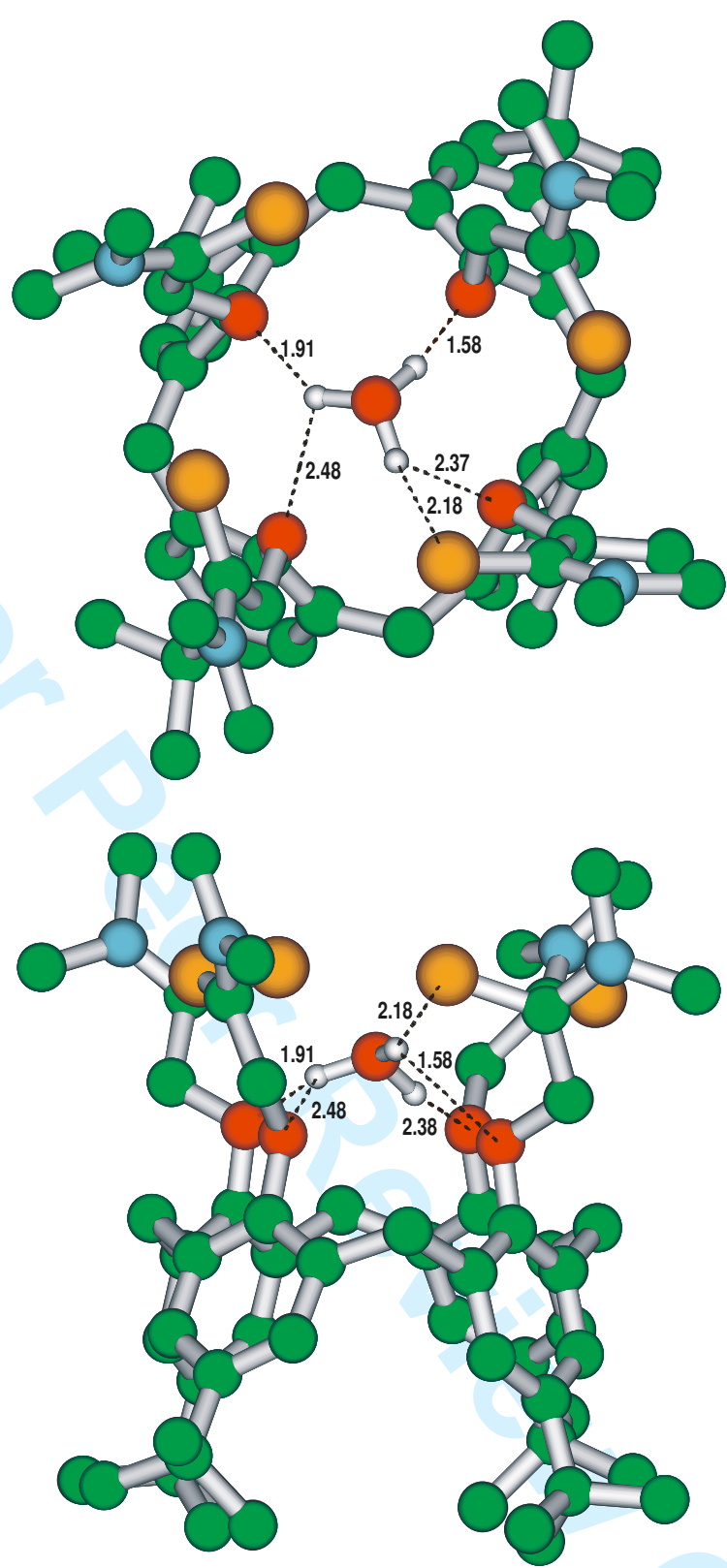

Fig. 4 Two projections of the DFT-optimized structure of the $\mathbf{1} \cdot \mathrm{H}_{3} \mathrm{O}^{+}$complex $(\mathrm{B} 3 \mathrm{LYP} / 6$ $31 \mathrm{G}(\mathrm{d})$, hydrogen atoms omitted except those of $\mathrm{H}_{3} \mathrm{O}^{+}$).

Although the symmetry of the calixarene part is predicted to be fairly near to $\mathrm{C}_{4}$ (cf. Fig. 4), the strong hydrogen bonds are not symmetrically distributed as it would seem to be so by NMR spectra. The above explanation that the structure is averaged by a fast motion of the $\mathrm{H}_{3} \mathrm{O}^{+}$ion in the coordination cavity seems to be hampered by a too high energy barrier connected with the necessary breaking of three to four hydrogen bonds. There is a high probability, however, that such barrier either does not exist or is much lower due to the 
relative nearness of two other sulfur atoms, which form weak hydrogen bonds with the ion. As the ion rotates, some hydrogen bonds are strengthened simultaneously as other are weakened and the energy surface traversed by this motion has shallow ripples rather than high peaks and deep valleys. It is also probable that the rotation can tunnel through these low barriers.

Finally, the calculated stabilization energy of the $\mathbf{1} \cdot \mathrm{H}_{3} \mathrm{O}^{+}$complex is $100.4 \mathrm{kcal} / \mathrm{mol}$, which is a rather high value expressing high stability of the complex under study. This again is in agreement with the findings of NMR. The determination of the actual stability constant of the complex $\mathbf{1} \cdot \mathrm{H}_{3} \mathrm{O}^{+}$in the organic phase of the two-phase water-nitrobenzene extraction system is underway in our laboratories.

In conclusion, we found that $\mathrm{H}_{3} \mathrm{O}^{+}$not only binds to $\mathbf{1}$ but, in doing so, influences its overall conformation forcing its calixarene cavity to adopt a more symmetric and open shape. This surely influences its properties as a host for some guest molecules. One can thus speculate that inclusion interactions of $\mathbf{1}$ and similar modified calixarenes could be changed by adding protons to the system, which opens interesting possibilities.

\section{EXPERIMENTAL}

Materials and samples. Nitrobenzene- $d_{5}$ and $p$-tert-butylcalix[4]arene-tetrakis $(N, N$ dimethylthioacetamide) (1) were purchased from Fluka, Buchs, Switzerland and were used as obtained. Preparation of hydrogen bis(1,2-dicarbollyl) cobaltate (HDCC) was described in Ref. [14]. Briefly, the cesium (CsDCC) analogue was prepared in the Institute of Inorganic

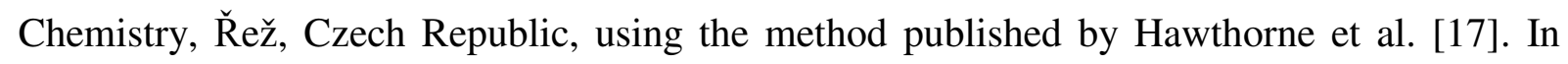
order to obtain its hydrogen analogue, HDCC, $0.2 \mathrm{~mol} / \mathrm{L}$ solution of CsDCC in nitrobenzene was twice shaken with equal volumes of $15 \% \mathrm{v} / \mathrm{v}$ n-propanol in $1 \mathrm{~mol} / \mathrm{L} \mathrm{H}_{2} \mathrm{SO}_{4}$ in distilled water, followed by tenfold equilibrium shaking with equal amounts of $1 \mathrm{~mol} / \mathrm{L} \mathrm{H}_{2} \mathrm{SO}_{4}$ and 
two equilibrations with distilled water. After separation of the phases, nitrobenzene was removed by distillation. The product was dried under high vacuum to a constant weight for two weeks. For NMR samples, $5 \times 10^{-6}$ mol of $\mathbf{1}$ was dissolved in a mixture of appropriate amounts of nitrobenzene- $d_{5}$ and $0.001 \mathrm{~mol} / \mathrm{L}$ solution of HDCC in the same solvent.

NMR measurements. ${ }^{1} \mathrm{H}$ and ${ }^{13} \mathrm{C}$ NMR spectra were measured at 300.13 and $75.45 \mathrm{MHz}$ frequency, respectively, with an upgraded Bruker Avance DPX300 spectrometer collecting 64 scans for ${ }^{1} \mathrm{H}$ NMR and $2 \times 10^{4}$ scans for each type of ${ }^{13} \mathrm{C}$ NMR spectra. In the latter case, DEPT45 sequence was used and spectra with coherence evolution delays adapted for the spin interaction constants $J_{\mathrm{CH}} 145,20,12$, and $6 \mathrm{~Hz}$, respectively, were superimposed in the presented ${ }^{13} \mathrm{C}$ NMR spectra. COSY-LR and NOESY 2D ${ }^{1} \mathrm{H}$ NMR spectra as well as HSQC and $\mathrm{HMBC}{ }^{1} \mathrm{H}^{13}{ }^{13}$ 2D correlation spectra were measured using an inverse-detection $\mathrm{z}$ gradient probe taking 1 kpoints and 256 increments in 640 scans. Phase shifted sine-bell weighting function was applied before Fourier transform.

Computational procedures. All calculations were performed using the GAUSSIAN 03 suite of programs [16]. The molecular equilibrium geometries were fully optimized without geometry constrains by using the Becke's three parameter functional of density functional theory with the correlation of Lee-Yang-Parr (B3LYP) and the 6-31G(d) basis set. Several local configurations near the achieved energy minimum were examined. As the renewed optimizations converged to the same molecular geometry, we believe the achieved energy minimum to be the global one.

Acknowledgements. This work was supported by the Academy of Sciences of the Czech Republic, Project T400500402, the Czech Science Foundation, Project 203/04/P168 and the Czech Ministry of Education, Youth and Sports, Projects MSM 4977751303, MSM 6046137307, MS 0021620835. 


\section{References}

1 Gutsche, C. D. Calixarenes Revisited. The Royal Society of Chemistry, Cambridge, 1998.

2 Saenger, W. Angew. Chem., Int. Ed. Engl. 1980, 19, 344-362.

3 Arduini, A.; Pochini, A.; Reverberi, S.; Ungaro, R. Tetrahedron 1986, 42, 20892100.

4 Arduini, A.; Ghidini, E.; Pochini, A.; Ungaro, R.; Andreetti, G.D.; Calestani, G.; Ugozzoli, F. J. Inclusion Phenom. 1988, 6, 119-134.

5 Arnaud-Neu, F.; Collins, E.M.; Deasy, M.; Ferguson, G.; Harris, S.J.; Kaitner, B.; Lough, A.J.; McKervey, M.A.; Marques, E.; Ruhl, B.L.; Schwing-Weill, M.J.; Seward, E.M. J. Am. Chem. Soc. 1989, 111, 8681-8691.

6 Arnaud-Neu, F.; Barrett, G.; Harris, S.J.; Owens, M.; McKervey, M.A.; SchwingWeill, M.J.; Schwinté, P. Inorg. Chem. 1993, 32, 2644-2650.

7 Ohto, K.; Murakami, E.; Shinohara, T.; Shiratsuchi, K.; Inoue, K.; Iwasaki, M. Anal. Chim. Acta 1997, 341, 275-283.

8 Ye, Z.; He, W.; Shi, X.; Zhu, L. J. Coord. Chem., 2001 54, 105-116.

9 Danil de Namor, A.F.; Chahine, S.; Kowalska, D.; Castellano, E.E.; Piro, O.E. J. Am. Chem. Soc. 2002, 124, 12824-12836.

10 Marcos, P. M.; Ascenso, J.R.; Segurado M.A.P.; Pereira, J.L.C. J. Inclusion Phenom. 2002, 42, 281-288.

11 Marcos, P.M.; Félix, S.; Ascenso, J.R.; Segurado, M.A.P.; Pereira, J.L.C.; KhazaeliPursa, P.; Hubscher-Bruder, V.; Arnaud-Neu, F. New J. Chem. 2004, 28, 748-755.

12 Makrlík, E.; Vaňura, P. Talanta 1985, 32, 423-429.

13 Kř́̌ž, J.; Makrlík, E.; Vaňura, P. Biopolymers, 2006, 81, 104-109. 
14 Kř́iž, J.; Dybal, J.; Makrlík, E. Biopolymers, 2006, 82, 536-548.

15 Gutsche, C. D. Aldrichimica Acta 1995, 28, 3-9.

16 Frisch, M. J.; Trucks, G. W.; Schlegel, H. B.; Scuseria, G. E.; Robb, M. A.; Cheeseman, J. R.; Montgomery, Jr., J. A.; Vreven, T.; Kudin, K. N.; Burant, J. C.; Millam, J. M.; Iyengar, S. S.; Tomasi, J.; Barone, V.; Mennucci, B.; Cossi, M.; Scalmani, G.; Rega, N.; Petersson, G. A.; Nakatsuji, H.; Hada, M.; Ehara, M.; Toyota, K.; Fukuda, R.; Hasegawa, J.; Ishida, M.; Nakajima, T.; Honda, Y.; Kitao, O.; Nakai, H.; Klene, M.; Li, X.; Knox, J. E.; Hratchian, H. P.; Cross, J. B.; Bakken, V.; Adamo, C.; Jaramillo, J.; Gomperts, R.; Stratmann, R. E.; Yazyev, O.; Austin, A. J.; Cammi, R.; Pomelli, C.; Ochterski, J. W.; Ayala, P. Y.; Morokuma, K.; Voth, G. A.; Salvador, P.; Dannenberg, J. J.; Zakrzewski, V. G.; Dapprich, S.; Daniels, A. D.; Strain, M. C.; Farkas, O.; Malick, D. K.; Rabuck, A. D.; Raghavachari, K.; Foresman, J. B.; Ortiz, J. V.; Cui, Q.; Baboul, A. G.; Clifford, S.; Cioslowski, J.; Stefanov, B. B.; Liu, G.; Liashenko, A.; Piskorz, P.; Komaromi, I.; Martin, R. L.; Fox, D. J.; Keith, T.; AlLaham, M. A.; Peng, C. Y.; Nanayakkara, A.; Challacombe, M.; Gill, P. M. W.; Johnson, B.; Chen, W.; Wong, M. W.; Gonzalez, C.; and Pople, J. A.; Gaussian 03, Revision C.02, Gaussian, Inc., Wallingford CT, 2004.

17 Hawthorne, M. F.; Young, D. C.; Andrews, T. D.; Howe, D. V.; Pilling, R. L.; Pitts, A. D.; Reintjes, M.; Warren, L. F.; Wegner, P. A. J. Am. Chem. Soc. 1968, 90, 879

18 Kř́̌ž, J.; Dybal, J.; Makrlík, E.; Vaňura, P. Supramolecular Chem. submitted 19 Čajan, M.; Lhoták, P.; Lang, J.; Dvořáková, H.; Stibor, I.; Koča, J. J. Chem. Soc. Perkin Trans., 2002, 2, 1922-1929

20 Lozynski, M.; Rusinska-Roszak, D.; Mack, H.-G. J. Phys. Chem. A 1998, 102, 2899

21 Wang, W. Z. Chem. Phys. Lett. 2005, 402, 54

22 Zhao, Y.; Truhlar, D. G. J. Chem. Theory Comput. 2005, 1, 415 


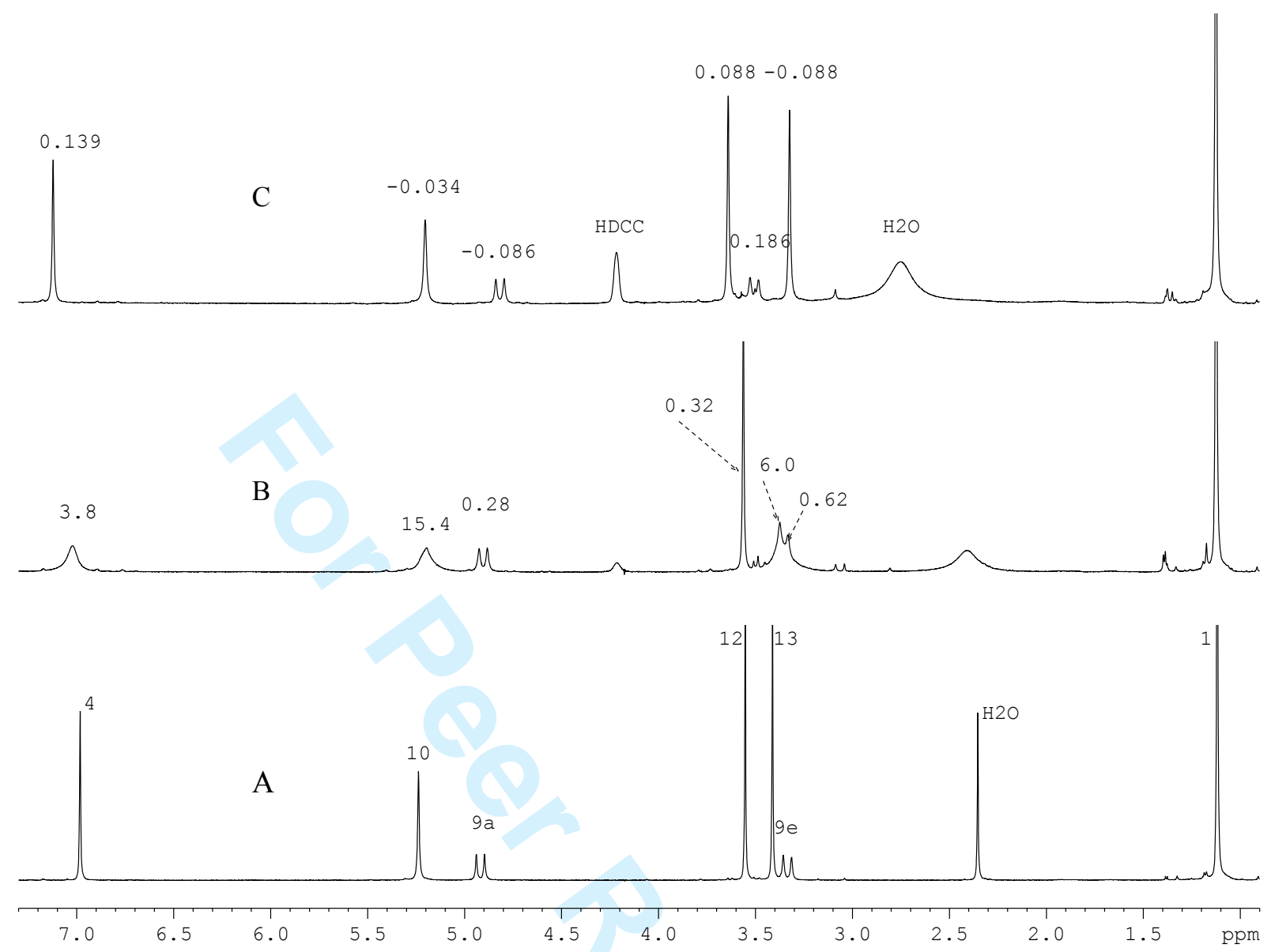




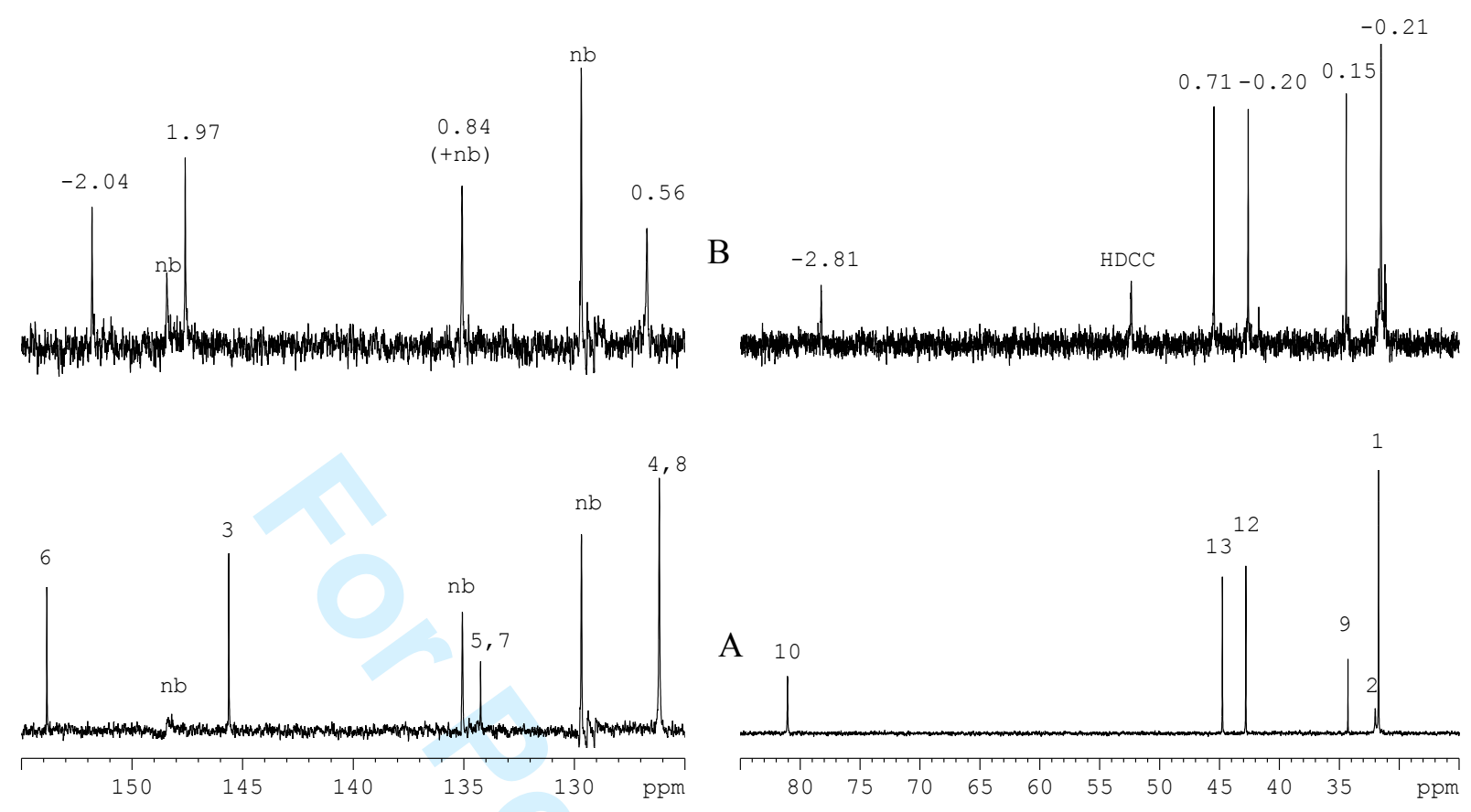

